\title{
Growth Characteristics of Landscaping Trees by Container Size in Production of Standard Size
}

\author{
Myeong II Jeong, Na Ra Jeong*, Seung Won Han, and Jae Soon Kim \\ Urban Agriculture Division, National Institute of Horticultural \& Herbal Science, RDA, Wanju 55365, South Korea
}

\begin{abstract}
The purpose of this study was to evaluate the effects of container size on growth of Zelkova serrata, Acer palmatum, Crataegus pinnatifida, Pinus densiflora, Chionanthus retusus, Ilex serrata, Viburnum erosum, and Hibiscus syriacus in container. This study used $22 \mathrm{~L}, 38 \mathrm{~L}$, and $52 \mathrm{~L}$ container and measured seedling height, root collar diameter, seeding quality index (SQI), biomass. Acer palmatum, Pinus densiflora and Ilex serrata were high in 22, Crataegus pinnatifida in $38 \mathrm{~L}$, and Zelkova serrata, Chionanthus retusus, Viburnum erosum, and Hibiscus syriacus in $52 \mathrm{~L}$ regarding the relative growth of height and root diameter in statistical significance. The H/D ratio was fine for Zelkova serrata, Pinus densiflora, Chionanthus retusus, Ilex serrata at $22 \mathrm{~L}$, Acer palmatum and Crataegus pinnatifida for $38 \mathrm{~L}$, and Viburnum erosum and Hibiscus syriacus for $52 \mathrm{~L}$. Seeding Weight of Acer palmatum, Pinus densiflora was heavy at $22 \mathrm{~L}$. Chionanthus retusus, Ilex serrata, Viburnum erosum, Hibiscus syriacus were heavy at $38 \mathrm{~L}$, Zelkova serrata, and Crataegus pinnatifida were heavy at 52 L. Zelkova serrata, Crataegus pinnatifida, Pinus densiflora, and Ilex serrata were fine at $22 \mathrm{~L}$, Acer palmatum, Chionanthus retusus, Viburnum erosum at $38 \mathrm{~L}$, Hibiscus syriacus at $52 \mathrm{~L}$ about T/R ratio. For SQI, Acer palmatum, and Pinus densiflora were high in $22 \mathrm{~L}$, Chionanthus retusus, Ilex serrata, and Viburnum erosum in 38 L, Zelkova serrata, Crataegus pinnatifida, and Hibiscus syriacus in 52 L. Seedling quality was considered to be appropriate when the growth was balanced between the above and below ground. As a result, it is effective to cultivate Acer palmatum and Pinus densiflora at $22 \mathrm{~L}$, Chionanthus retusus, Ilex serrata, and Viburnum erosum at $38 \mathrm{~L}$, and Zelkova serrata, Crataegus pinnatifida, and Hibiscus syriacus at $52 \mathrm{~L}$.
\end{abstract}

Keywords: landscape materials, planting, container type, growth performances

\section{Introduction}

As the level of income and people's interest in the environment such as expansion of green spaces have been increasing, landscape trees continue to be produced. The production of landscape trees slightly decreased to 77,664,000 trees in 2014 due to the slowdown in the construction and architecture industry, and recovered the average number in 2015 (110,043,000 trees), up by $41.7 \%$ from the previous year (KFS, 2014). In addition, landscape trees have been used for various purposes, such as creating green spaces or gardens, or using them as street trees. As the aesthetic aspects of flowers and trees have been highlighted, the demand for beautiful flowers and trees of outstanding shapes, as well as their standardized quality have been increasing. Most of the landscape trees used in Korea, however, are grown in open ground,

This study was supported by the research project of the Rural Development Administration (PJ010190022017).

Received: September 30, 2017, Revised: October 6, 2017, Accepted: October 7, 2017

*Comesponding author: jnr202@korea.kr 
and thus it has been difficult to produce trees of the standardized size, resulting in high costs for producing and digging trees out of the open ground. The process of working is complicated, and it is also difficult to produce trees of the standardized quality (Kim and Kim, 2001). A series of issues are often reported cause of defect after transplanting landscape trees, such as drying, transplanting at inappropriate times, unsuitable species of trees, etc. (Kim, 2017), which has raised the importance of developing measures to reduce the defect rate of landscape trees in landscape projects. Cultivating landscape trees in containers has emerged as an alternative in order to reduce costs for plating and maintaining trees and to increase the survival rate of trees after transplanting, and the number of landscape trees grown in such ways has been gradually increasing. The scale of Pinus densiflora seedlings grown in containers doubled in two years from $4,966,000$ in 2012 to 9,064,000 in 2014 (KFS, 2016). The survival rate of trees produced in containers and transplanted at inappropriate times is high, and they can be produced in a uniform size (Allen et al., 2017). It is also recognized as a useful way to improve the survival of trees in places unfavorable for the growth of trees (Kim and Kim, 2000).

The United States, Japan and many countries in Europe have already developed new species and technologies for standardization and established mass-production systems in order to produce high-quality landscape trees. In particular, they have introduced advanced production and management techniques and thus improved productivity and efficiency through large-scale tree nurseries using container cultivation techniques. The Korea Forest Service (KFS) has made efforts to expand container cultivation systems for the standardization of producing landscape trees, and also planned to increase its support for projects that link containers and open grounds for producing mid- and large-scale standardized seedlings from 30 facilities in 2016 to 100 facilities in 2018 (KFS, 2014).

Earlier studies on the production of trees using containers have mainly focused on the survival rate of trees grown in containers after transplanting, its economic feasibility, the materials of containers and the growth of trees in container of those on the survival rate of trees grown in containers after transplanting (Dana and Blessing, 1994; Appleton, 1995; Kim and Kim, 2001), the survival rate of trees grown in containers was high, and their rootlets grew well. However, no significant difference in the growth of trees was reported. Kim and Kim (2001) analyzed the wilting and withering rates of trees cultivated in containers, and pointed out that methods using containers are effective in reducing the defect rate of trees that were transplanted at inappropriate times and into special soil environments. Kim and Kim (1999) conducted a study on the economic feasibility of container cultivation, and compared the production costs of container and open ground cultivation methods. It was found that costs for regularly transplanting and managing plants in containers is over 4 times higher than the costs for cultivating plants in open grounds, but that the labor cost of container cultivation for digging trees out is only $50 \%$ of the open ground cultivation method. They concluded that the container production method is more effective considering the decreasing labor cost. Kang (2008) analyzed the management and labor costs, and the growth rate of trees grown in containers made of non-woven fabric, and reported that the uniformity of trees grown in containers was high, and thus that the containers were effective in producing uniform trees. Studies on the materials of containers (Park, 1999; Kim, 2000; Kim, 2002; Lee, 2002; Jung et al., 2016) found that containers made of non-woven fabric, plastic nets and growing bags were effective for the growth of trees. Cho (2014) compared different techniques of cultivation using containers, such as belowground, half-belowground and aboveground cultivation techniques. Studies on the growth characteristics of container cultivation (Amoroso et al., 2010; Gilman et al., 2010) found that air-pot containers can strengthen root pruning for moving. Warren and Blazich (2001) compared the growth of the roots of Rhododendron schlippenbachii Maxim. and Ilex crenata Thunb. depending on the four types of containers, and examined the relationship between the growth of roots and containers. Several studies on the growth of trees grown in containers have been conducted overseas, while those conducted in Korea have mostly focused on the effects of transplanting trees grown in containers on their production and survival. It has been known that the larger the containers used to cultivate trees, the 
better they grow. However, the larger the containers, the more water leaks due to watering and fertilizing, and thus it is necessary to apply the proper size of container in order to address environmental issues, increase economic feasibility and maintain a proper amount of fertilizers (Cho et al., 2012).

Therefore, this study aimed to identify the proper size of container for each species of landscape trees in consideration of the impact of changes in the growth environment depending on the size of container on the physiological and morphological characteristics of plants. To do so, among landscape trees, those that can be utilized for trees were selected and changes in their growth conditions depending on the size of container were analyzed, suggesting the proper size of container for each species.

\section{Research Method}

\section{Plants for experiment}

In order to determine the proper size of container for each species of plants, those that are widely used as landscape trees were selected as test plants. The Korean Forest Service (KFS) releases the production volume and amount of key landscape trees annually (KFS, 2016), and those that are produced in a large volume and can be widely used in gardens were selected out of them as follows: trees including Zelkova serrata, Acer palmatum, Crataegus pinnatifida, Pinus densiflora, and Chionanthus retusus, and shrubs including Ilex serrata, Viburnum erosum, and Hibiscus syriacus. For this experiment, an experimental site was created in the site of the National Institute of Horticultural and Herbal Science (Fig. 1), and three-year-old plants that showed similar growth conditions were prepared. In May, 2015, they were planted in three types of containers, and the same process was repeated three times per each species.

\section{Methods of experiment}

Based on the most widely used container $(38 \mathrm{~L}(\mathrm{R}=$ around $10 \mathrm{~cm}))$, three types of containers $(22 \mathrm{~L}, 38 \mathrm{~L}$ and $52 \mathrm{~L})$ were selected (Table 1). All the three containers were made of plastic, and the size of each container was as follows: $22 \mathrm{~L}$ (height: $28.0 \mathrm{~cm}$, average diameter: $31.5 \mathrm{~cm}$ ), $38 \mathrm{~L}$ (height: $30.2 \mathrm{~cm}$, average diameter: $41.4 \mathrm{~cm}$ ), and $52 \mathrm{~L}$ (height: 34.0

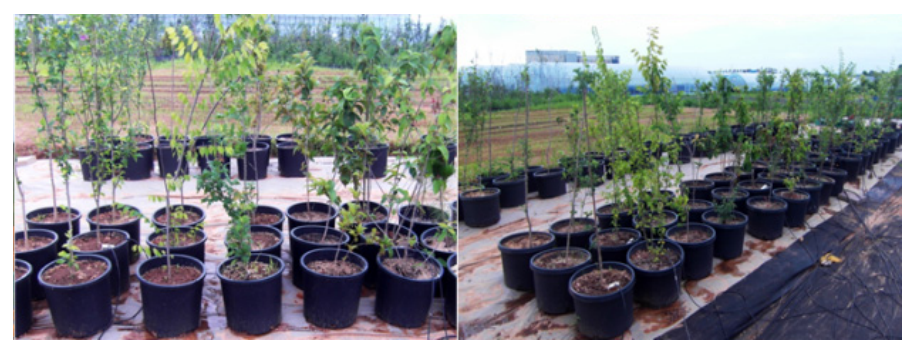

Figure 1. Photo of experimental site.

Table 1. Characteristics of containers used on this study.

\begin{tabular}{lccccc}
\hline \multirow{2}{*}{ Container type } & \multicolumn{3}{c}{ Size $(\mathrm{cm})$} & \multirow{2}{*}{ Volume (L) } & Material \\
\cline { 2 - 3 } & Top diameter & Bottom diameter & Height & & \\
\hline CH-7 & 33.0 & 30.0 & 28.0 & 22 & plastic \\
CH-10 & 45.0 & 37.7 & 30.2 & 38 & plastic \\
CH-15 & 46.5 & 42.5 & 34.0 & 52 & plastic \\
\hline
\end{tabular}


$\mathrm{cm}$, average diameter: $44.5 \mathrm{~cm}$ ). Test plants were planted in the containers filled with nursery bed soil (Sunshine mix 4, Sun Gro Horticulture, Canada, peat-moss 60-70\%, perlite 30-40\%). After planting, they were watered once every week, and a slow release fertilizer (Osmocote, Scotts, USA, 11-11-17+2MgO+TE), $60 \mathrm{~g}$, was applied once every year. To prevent unpredictable damage by diseases and insects, an insecticide and germicide were sprayed twice in summer.

\section{Measurement and analysis methods}

To examine changes in the growth of plants depending on the size of container, the first month after planting was recognized as the period of adaptation to containers, and the height, root collar diameter and crown width of plants were repeatedly measured once every 30 days from July, 2015. The relative growth ratio ((final growth amount - initial growth amount)/the number of growth days) of the height and root collar diameter of plants, and their H/D ratio (SQ; Sturdiness Quotient $=$ height/root collar diameter), which is used to assess the health of seedlings were calculated to examine the growth characteristics of plants (Hughes and Freeman, 1967; Lee et al., 2006; Bayala et al., 2009). At the end of this experiment in November, 2016, the fresh weight of the aboveground and belowground parts of plants were measured respectively. Based on the measured fresh weight of plants, the fresh weight of each part, the total fresh weight and the $\mathrm{T} / \mathrm{R}$ ratio (the ratio of aboveground to belowground biomass, top weight/root weight) of plants were calculated (Sestak et al., 1971; Dominguez-Lerena et al., 2006). In addition, the seedling quality index (SQI = Seedling weight (g)/(H/D ratio + $\mathrm{T} / \mathrm{R}$ ratio)) was calculated to assess the quality of cultivated seedlings in a comprehensive consideration (Deans et al., 1989; Cho et al., 2012).

The measured data were analyzed using the SPSS statistical analysis program (SPSS ver. 12.0). Since the number of data is small, the statistical significance of data depending on the size of container was evaluated using nonparametric tests including the Kruskal-Wallis test and Mann-Whitney U test.

\section{Results and Discussions}

\section{Growth characteristics of aboveground and belowground parts}

The growth conditions of each species differed depending on the size of container (Fig. 2). For the first year after planting, there was no significant difference in the growth of plants, and some species and container types showed survival issues such as reduced growth. After 330 days, plants continued to grow. In particular, Pinus densiflora, Chionanthus retusus and Hibiscus syriacus showed nearly no difference in growth for the first year, and the growth of Crataegus pinnatifida and Ilex serrata was even reduced until they successfully survived. In the case of Zelkova serrata and Chionanthus retusus, the bigger the size of container, the higher the height of the plants. The height of Acer palmatum grown in the $22 \mathrm{~L}$ container was highest, followed by $52 \mathrm{~L}$ and $38 \mathrm{~L}$, and especially the growth speed and amount of those grown in the $38 \mathrm{~L}$ container were much lower than those of plants grown in other container types. Crataegus pinnatifida showed similar growth conditions regardless of the size of container. The height of Pinus densiflora grown in the 38L and $22 \mathrm{~L}$ containers was similar, but that of those grown in the $52 \mathrm{~L}$ container was relatively lower. As these results indicate, large containers do not necessarily lead to more growth, but the proper size of container needs to be used. Ilex serrata grew well in smaller containers, and the those grown in the $52 \mathrm{~L}$ container did not show any change in height after 330 days. Viburnum erosum and Hibiscus syriacus grew well in the $52 \mathrm{~L}$ container, but did not show much change in the $22 \mathrm{~L}$ container, which indicates that it will be more effective to cultivate the shrubs in larger containers for better growth.

The results of the root collar diameter of plants also showed similar patterns (Fig. 3). In the case of Zelkova serrata, the 
larger the size of container, the wider the root collar diameter of its trees. In particular, those grown in the $52 \mathrm{~L}$ container showed significant changes in root collar diameter, but those grown in the other two container types did not show much difference. Acer palmatum and Ilex serrata had a wider root collar diameter in smaller containers, and in particular, those grown in the $22 \mathrm{~L}$ container grew well, but those grown in the rest two container types showed nearly no difference. Ilex serrata showed nearly no growth in the $52 \mathrm{~L}$ container, and the larger the size of container, the less their trees grew.

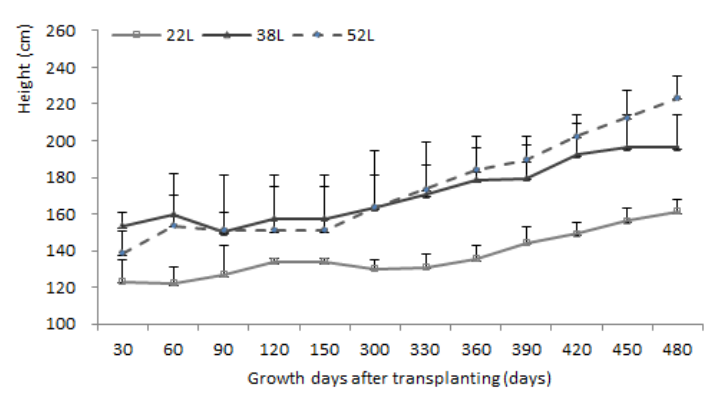

A

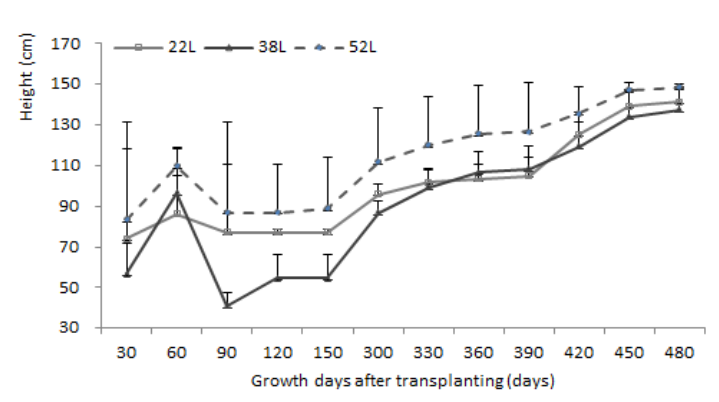

C

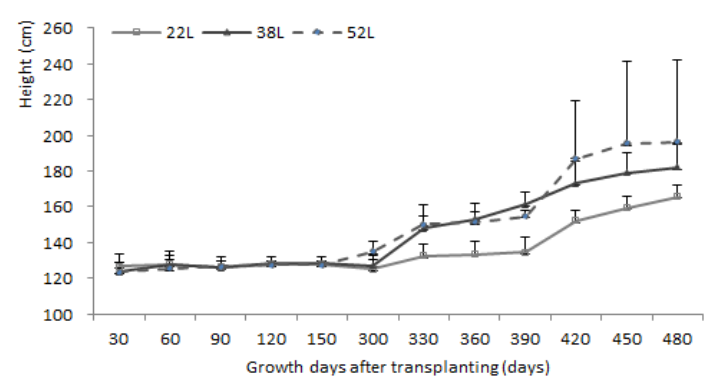

$\mathrm{E}$

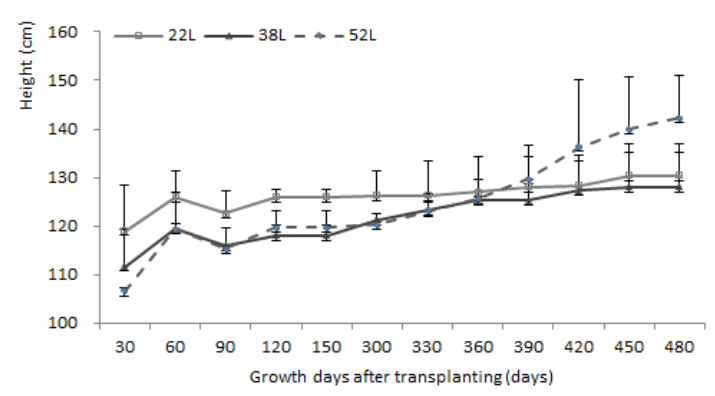

G

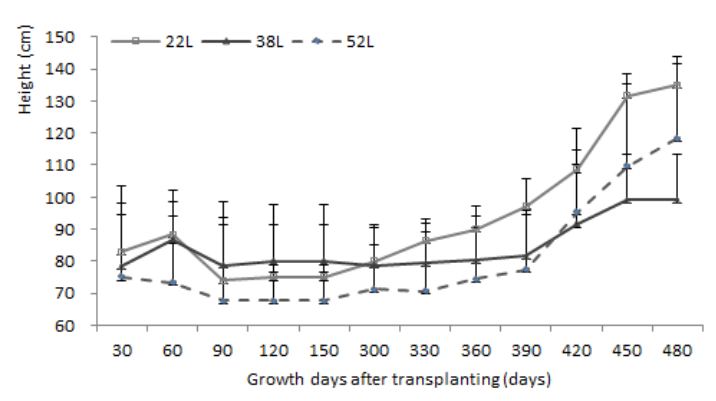

B

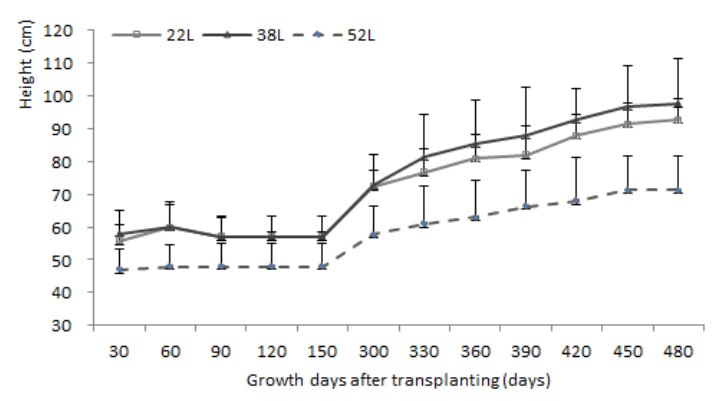

D

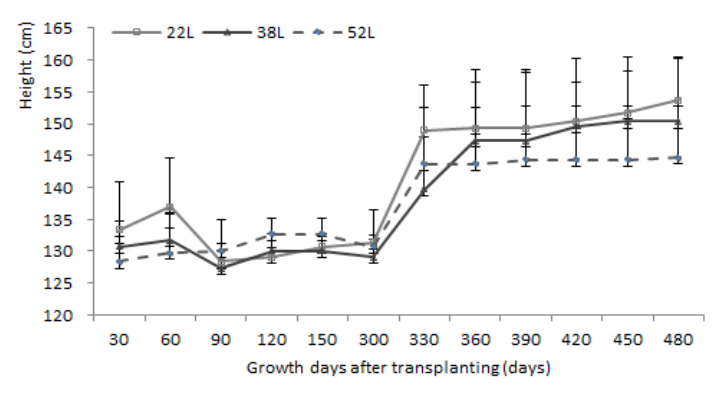

$\mathrm{F}$

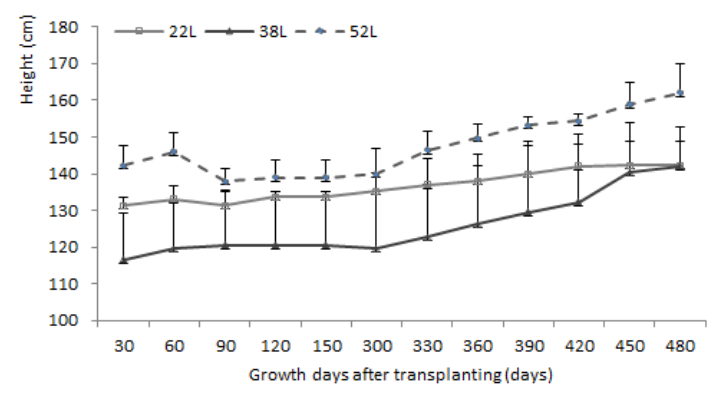

$\mathrm{H}$

Figure 2. The growth patterns of height of plants grown at three different container types.

$\mathrm{A}=$ Zelkova serrata; $\mathrm{B}=$ Acer palmatum; $\mathrm{C}=$ Crataegus pinnatifida; $\mathrm{D}=$ Pinus densiflora; $\mathrm{E}=$ Chionanthus retusus; $\mathrm{F}=$ Ilex serrata; $\mathrm{G}=$ Viburnum erosum; $\mathrm{H}=$ Hibiscus syriacus. 
Crataegus pinnatifida and Chionanthus retusus had a wider root collar diameter in larger containers, but the difference was not significant. Viburnum erosum did not show any growth in every container type for the first year after planting, but since then, the larger the size of container, the more their trees grew. Pinus densiflora showed nearly no difference in root collar diameter between different container types, but, after 450 days, those grown in the $22 \mathrm{~L}$ container grew rapidly. These results do not coincide with those of Ortega et al. (2006) that the larger the size of container, the wider the root

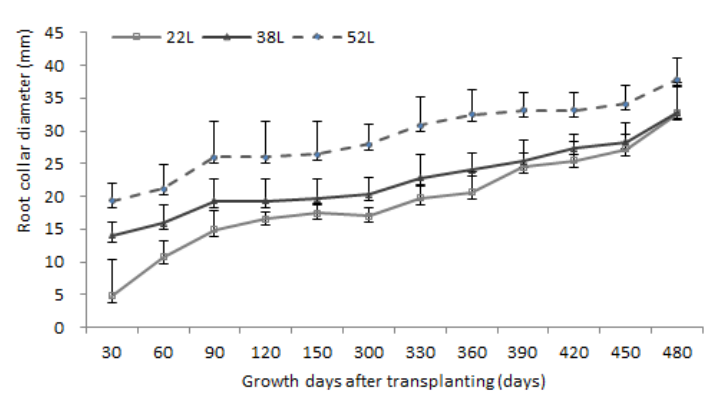

A

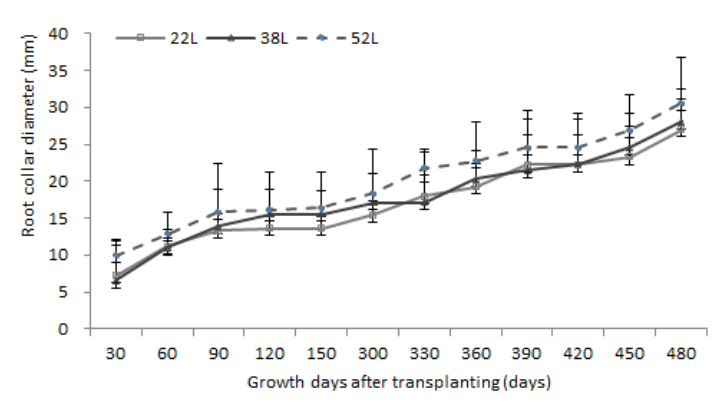

C

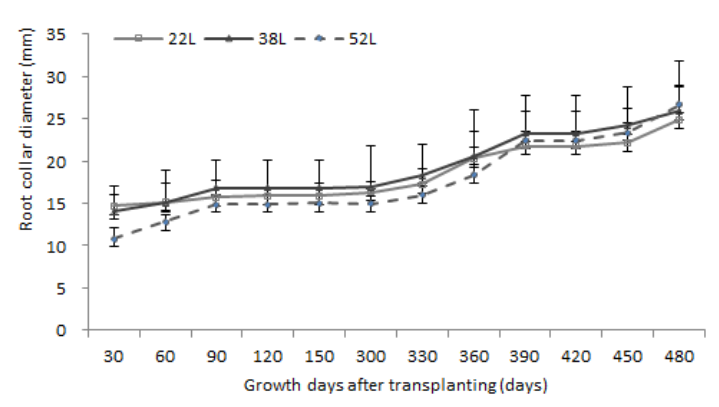

$E$

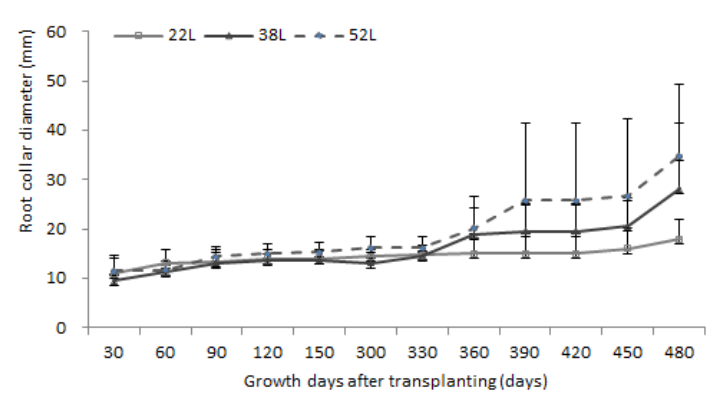

G

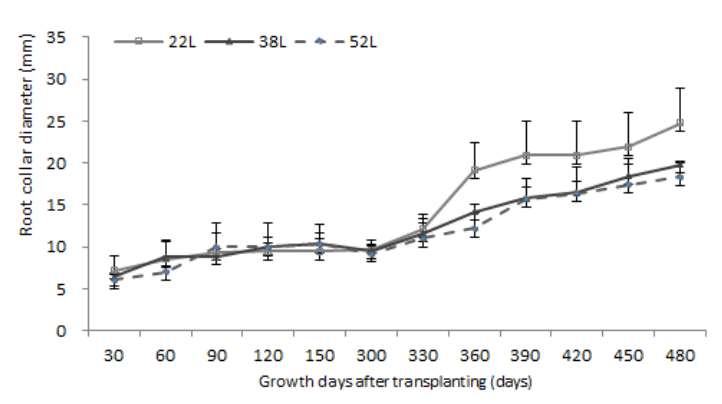

B

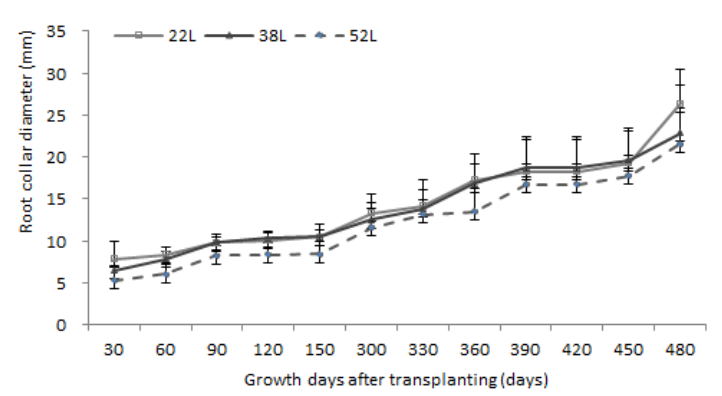

$\mathrm{D}$

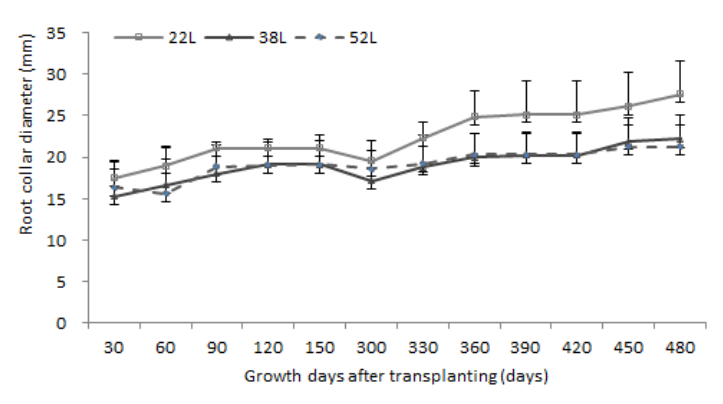

$\mathrm{F}$

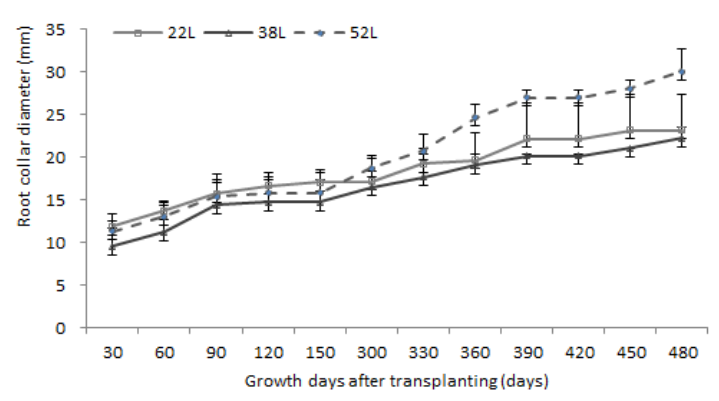

$\mathrm{H}$

Figure 3. The growth patterns of root collar diameter of plants grown at three different container types.

$\mathrm{A}=$ Zelkova serrata; $\mathrm{B}=$ Acer palmatum; $\mathrm{C}=$ Crataegus pinnatifida; $\mathrm{D}=$ Pinus densiflora; $\mathrm{E}=$ Chionanthus retusus; $\mathrm{F}=$ Ilex serrata; $\mathrm{G}=$ Viburnum erosum; $\mathrm{H}=$ Hibiscus syriacus. 
collar diameter, and the higher the height. This is attributable to the fact that smaller seedlings were used in the study for the production of saplings than those used in this study. This also indicates that the larger the volume of container, the more trees can grow to a ceratin extent, but that, after then, larger containers do not necessarily mean more efficient. Still, during the period of this experiment, the height and root collar diameter of all the test plants tended to continue to grow,

Table 2. The height, root collar diameter and H/D ratio of plants grown at three different container types.

\begin{tabular}{|c|c|c|c|c|c|c|c|c|c|c|}
\hline \multirow{3}{*}{ Species } & \multirow{3}{*}{$\begin{array}{l}\text { Container } \\
\text { type }(\mathrm{L})\end{array}$} & \multicolumn{4}{|c|}{ Height } & \multicolumn{4}{|c|}{ Root collar diameter } & \multirow{3}{*}{$\begin{array}{l}\mathrm{H} / \mathrm{D} \text { ratio } \\
(\mathrm{cm} / \mathrm{mm})\end{array}$} \\
\hline & & \multicolumn{2}{|c|}{$\begin{array}{l}\text { Growth increment } \\
\qquad(\mathrm{cm})\end{array}$} & \multicolumn{2}{|c|}{$\begin{array}{c}\text { RGR } \\
\text { (mm/day) }\end{array}$} & \multicolumn{2}{|c|}{$\begin{array}{l}\text { Growth increment } \\
(\mathrm{mm})\end{array}$} & \multicolumn{2}{|c|}{$\begin{array}{c}\text { RGR } \\
\text { (mm/day) }\end{array}$} & \\
\hline & & Mean \pm SD & $\chi^{2 z}$ & Mean \pm SD & $\chi^{2}$ & Mean \pm SD & $\chi^{2}$ & Mean \pm SD & $\chi^{2}$ & \\
\hline \multirow{3}{*}{$\begin{array}{l}\text { Zelkova } \\
\text { serrata }\end{array}$} & 22 & $38.0 \pm 12.5 \mathrm{~b}^{\mathrm{y}}$ & & $0.79 \pm 0.26 \mathrm{~b}$ & & $27.9 \pm 4.0$ & & $0.06 \pm 0.008$ & & $5.0 \pm 0.9$ \\
\hline & 38 & $42.7 \pm 10.5 \mathrm{~b}$ & $5.60^{*}$ & $0.89 \pm 0.22 \mathrm{~b}$ & $5.60^{*}$ & $18.8 \pm 2.6$ & 5.47 & $0.04 \pm 0.005$ & 5.47 & $6.0 \pm 0.8$ \\
\hline & 52 & $84.7 \pm 5.0 \mathrm{a}$ & & $1.76 \pm 0.10 \mathrm{a}$ & & $18.6 \pm 0.9$ & & $0.04 \pm 0.002$ & & $5.9 \pm 0.3$ \\
\hline \multirow{3}{*}{$\begin{array}{l}\text { Acer } \\
\text { palmatum }\end{array}$} & 22 & $52.0 \pm 25.2$ & & $1.08 \pm 0.53$ & & $17.6 \pm 7.9$ & & $0.04 \pm 0.016$ & & $5.8 \pm 1.5$ \\
\hline & 38 & $20.7 \pm 20.6$ & 3.92 & $0.43 \pm 0.43$ & 3.92 & $13.4 \pm 0.1$ & 0.80 & $0.03 \pm 0.000$ & 0.80 & $5.0 \pm 0.8$ \\
\hline & 52 & $43.3 \pm 2.9$ & & $0.90 \pm 0.06$ & & $12.3 \pm 2.4$ & & $0.03 \pm 0.005$ & & $6.6 \pm 1.8$ \\
\hline \multirow{3}{*}{$\begin{array}{l}\text { Crataegus } \\
\text { pinnatifida }\end{array}$} & 22 & $67.3 \pm 31.2$ & & $1.40 \pm 0.65$ & & $19.8 \pm 8.9$ & & $0.04 \pm 0.019$ & & $5.7 \pm 1.7$ \\
\hline & 38 & $80.7 \pm 17.8$ & 0.62 & $1.68 \pm 0.37$ & 0.62 & $21.6 \pm 6.0$ & 0.80 & $0.05 \pm 0.013$ & 0.80 & $5.2 \pm 1.5$ \\
\hline & 52 & $65.3 \pm 33.7$ & & $1.36 \pm 0.70$ & & $20.6 \pm 0.4$ & & $0.04 \pm 0.001$ & & $4.9 \pm 0.3$ \\
\hline \multirow{3}{*}{$\begin{array}{l}\text { Pinus } \\
\text { densiflora }\end{array}$} & 22 & $37.0 \pm 12.5 \mathrm{a}$ & & $0.77 \pm 0.26 \mathrm{a}$ & & $18.5 \pm 4.1$ & & $0.04 \pm 0.009$ & & $3.5 \pm 0.6$ \\
\hline & 38 & $39.7 \pm 7.0 \mathrm{a}$ & $3.38^{*}$ & $0.83 \pm 0.15 \mathrm{a}$ & $3.38^{*}$ & $16.5 \pm 5.5$ & 0.27 & $0.03 \pm 0.011$ & 0.27 & $4.3 \pm 0.5$ \\
\hline & 52 & $24.3 \pm 4.5 \mathrm{~b}$ & & $0.51 \pm 0.09 \mathrm{~b}$ & & $16.3 \pm 2.5$ & & $0.03 \pm 0.005$ & & $3.3 \pm 0.5$ \\
\hline \multirow{3}{*}{$\begin{array}{l}\text { Chionanthus } \\
\text { retusus }\end{array}$} & 22 & $39.0 \pm 23.8$ & & $0.81 \pm 0.50$ & & $10.2 \pm 5.4$ & & $0.02 \pm 0.011$ & & $6.9 \pm 1.6$ \\
\hline & 38 & $58.7 \pm 16.3$ & 1.69 & $1.22 \pm 0.34$ & 1.69 & $11.8 \pm 2.8$ & 3.47 & $0.02 \pm 0.006$ & 3.47 & $7.3 \pm 1.8$ \\
\hline & 52 & $73.0 \pm 49.8$ & & $1.52 \pm 1.04$ & & $15.9 \pm 3.4$ & & $0.03 \pm 0.007$ & & $7.5 \pm 2.3$ \\
\hline \multirow{3}{*}{$\begin{array}{l}\text { Ilex } \\
\text { serrata }\end{array}$} & 22 & $20.3 \pm 8.1$ & & $0.42 \pm 0.17$ & & $10.1 \pm 1.2$ & & $0.02 \pm 0.002$ & & $5.6 \pm 0.7$ \\
\hline & 38 & $19.7 \pm 9.1$ & 1.08 & $0.41 \pm 0.19$ & 1.08 & $6.9 \pm 5.1$ & 3.23 & $0.01 \pm 0.011$ & 3.23 & $6.9 \pm 1.1$ \\
\hline & 52 & $16.3 \pm 7.1$ & & $0.34 \pm 0.15$ & & $4.9 \pm 0.3$ & & $0.01 \pm 0.001$ & & $6.8 \pm 0.4$ \\
\hline \multirow{3}{*}{$\begin{array}{l}\text { Viburnum } \\
\text { erosum }\end{array}$} & 22 & $11.3 \pm 9.0 \mathrm{~b}$ & & $0.24 \pm 0.19 \mathrm{~b}$ & & $7.0 \pm 1.4$ & & $0.01 \pm 0.003$ & & $7.5 \pm 1.3$ \\
\hline & 38 & $16.3 \pm 0.6 \mathrm{~b}$ & 5.73 & $0.34 \pm 0.01 \mathrm{~b}$ & 5.73 & $18.6 \pm 12.4$ & 1.89 & $0.04 \pm 0.026$ & 1.89 & $5.5 \pm 2.9$ \\
\hline & 52 & $35.7 \pm 9.3 \mathrm{a}$ & & $0.74 \pm 0.19 a$ & & $23.3 \pm 14.8$ & & $0.05 \pm 0.031$ & & $4.7 \pm 2.4$ \\
\hline \multirow{3}{*}{$\begin{array}{l}\text { Hibiscus } \\
\text { syriacus }\end{array}$} & 22 & $11.0 \pm 5.2 \mathrm{~b}$ & & $0.23 \pm 0.11 \mathrm{~b}$ & & $11.3 \pm 3.3 \mathrm{~b}$ & & $0.02 \pm 0.007 \mathrm{~b}$ & & $6.3 \pm 0.9$ \\
\hline & 38 & $25.3 \pm 2.5 \mathrm{a}$ & $6.01 *$ & $0.53 \pm 0.05 \mathrm{a}$ & $6.01 *$ & $12.6 \pm 3.4 \mathrm{~b}$ & $5.42 *$ & $0.03 \pm 0.007 \mathrm{~b}$ & $5.42 *$ & $6.4 \pm 0.9$ \\
\hline & 52 & $19.7 \pm 5.5 \mathrm{a}$ & & $0.41 \pm 0.11 \mathrm{a}$ & & $18.7 \pm 1.9 \mathrm{a}$ & & $0.04 \pm 0.004 \mathrm{a}$ & & $5.4 \pm 0.7$ \\
\hline
\end{tabular}

Growth increment $=$ Growth for 480 days- growth for 30 days; RGR (Relative Growth Ratio) $=$ (Growth for 480 days- growth for 30 days) $/ 480$ days; $H / D$ Ratio $=$ Height $/$ Root collar diameter ratio.

${ }^{\mathrm{z}}$ Kruskal-wallis Anova.

${ }^{\mathrm{y}}$ Post hoc test (based on Mann-whitney U test at 5\% level) after Kruskal-wallis Anova, The same letter on the column for each trees and index is not significantly different.

$* * p<.01,{ }^{*} p<.05$. 
indicating that all of them are suitable for container cultivation.

The height of relative growth ratio of Zelkova serrata grown in the $52 \mathrm{~L}$ container was high, but the root collar diameter of relative growth ratio of Zelkova serrata grown in the $22 \mathrm{~L}$ container was high. However, since there was no statistically significant difference between different container types, it will be necessary to examine other growth indicators. Trees of Acer palmatum and lex serrata grown in the $22 \mathrm{~L}$ container showed a higher growth both in height and root collar diameter, and their relative growth rate, and thus they can be cultivated also in the $22 \mathrm{~L}$ container. Crataegus pinnatifida grown in the $38 \mathrm{~L}$ container showed a higher growth both in height and root collar diameter than those grown in other container types. Trees of Chionanthus retusus and Viburnum erosum grown in the $52 \mathrm{~L}$ container showed a higher growth both in height and root collar diameter, and, in particular, Viburnum erosum showed a statistically significant difference in height growth between different container types. In the case of Hibiscus syriacus, those grown in $38 \mathrm{~L}$ the container showed a higher growth in height, and those grown in the $52 \mathrm{~L}$ container showed a higher growth in root collar diameter. However, considering the statistical significance of the data on the height of those grown in the $38 \mathrm{~L}$ and $52 \mathrm{~L}$ containers, it seems to be more effective to cultivate Hibiscus syriacus in the $52 \mathrm{~L}$ container. In the case of Pinus densiflora, the height of those grown in the $38 \mathrm{~L}$ container, and the root collar diameter of those grown in the $22 \mathrm{~L}$ container were higher. However, considering that there was no statistically significant difference in height between those grown in the $22 \mathrm{~L}$ and $38 \mathrm{~L}$ containers, Pinus densiflora can be cultivated also in the $22 \mathrm{~L}$ container. The H/D ratio, a ratio of aboveground to belowground growth, is used to assess the health of seedlings (Deans et al., 1989), and it is known that seedlings that show a higher H/D ratio are more vulnerable to stresses like wind, drying and low temperature (Burdett, 1990; Grossniclke, 2012). It was also reported that, in the process of cultivating seedlings in containers, the containers that showed the highest quality in most species also showed relatively the lowest H/D ratio (Cho et al., 2012). The H/D ratio of Zelkova serrata, Chionanthus retusus, and Ilex serrata was highest in the $52 \mathrm{~L}$ container, and that of Crataegus pinnatifida, Pinus densiflora, Viburnum erosum and Hibiscus syriacus was highest in the $22 \mathrm{~L}$ container. That of Acer palmatum was highest in the $38 \mathrm{~L}$ container (Table 2). However, since there was no statistically significant difference in the H/D ratio of all the species between different container types, it will be necessary to assess other growth indicators in a comprehensive consideration in order to determine the proper size of container for each species. In the cases of Zelkova serrata, Acer palmatum, and Chionanthus retusus, the higher the growth amount, the higher the H/D ratio, which is attributable to the fact that their aboveground part tended to overgrow their belowground part.

\section{Fresh weight and seedling quality index (SQI)}

In general, the larger the volume of container, the higher the production of plants (Jinks and Mason, 1998; Cho et al., 2012; Song et al., 2012), but the analysis results of fresh weight depending on the size of container found that each species showed different results (Table 3). The total fresh weight of Zelkova serrata and Crataegus pinnatifida regardless of aboveground and belowground parts was highest in the $52 \mathrm{~L}$ container, and that of Chionanthus retusus and Ilex serrata, highest in the $38 \mathrm{~L}$ container. The fresh weight of the aboveground part of Acer palmatum was highest in the $52 \mathrm{~L}$ container, and the fresh weight of its belowground part and the total weight were highest in the $22 \mathrm{~L}$ container. However, since there was no statistically significant difference between the two container types, it will be necessary to examine other indicators. The fresh weight of the aboveground part of Pinus densiflora was highest in the $38 \mathrm{~L}$ container, and the fresh weight of its belowground part and the total weight were highest in the $22 \mathrm{~L}$ container. Since there was no statistically significant difference between the two types, it can be grown in even in the $22 \mathrm{~L}$ container. The fresh weight of the aboveground part of Viburnum erosum was highest in the $52 \mathrm{~L}$ container, and the fresh weight of its belowground part 
Table 3. The effect of container types on the biomass production, T/R ratio and SQI.

\begin{tabular}{|c|c|c|c|c|c|c|c|c|c|c|c|}
\hline \multirow{3}{*}{ Species } & \multirow{3}{*}{$\begin{array}{l}\text { Container } \\
\text { type }(\mathrm{L})\end{array}$} & \multicolumn{6}{|c|}{ Weight } & \multirow{2}{*}{\multicolumn{2}{|c|}{$\mathrm{T} / \mathrm{R}$ ratio }} & \multirow{2}{*}{\multicolumn{2}{|c|}{ SQI }} \\
\hline & & \multicolumn{2}{|l|}{ Stem } & \multicolumn{2}{|l|}{ Root } & \multicolumn{2}{|l|}{ Seeding } & & & & \\
\hline & & Mean \pm SD & $\chi^{2 z}$ & Mean \pm SD & $x^{2}$ & Mean \pm SD & $x^{2}$ & Mean \pm SD & $\chi^{2}$ & Mean \pm SD & $\chi^{2}$ \\
\hline \multirow{3}{*}{$\begin{array}{l}\text { Zelkova } \\
\text { serrata }\end{array}$} & 22 & $726.7 \pm 117.2 b^{y}$ & & $356.7 \pm 35.1 \mathrm{~b}$ & & $1083.3 \pm 144.3 \mathrm{~b}$ & & $2.0 \pm 0.2$ & & $156.9 \pm 35.6 \mathrm{~b}$ & \\
\hline & 38 & $1256.7 \pm 141.9 \mathrm{a}$ & $6.46^{*}$ & $593.3 \pm 41.6 \mathrm{a}$ & $6.46^{*}$ & $1850.0 \pm 183.3 \mathrm{a}$ & $6.46^{*}$ & $2.1 \pm 0.1$ & 0.27 & $228.2 \pm 30.4 \mathrm{a}$ & $5.96^{*}$ \\
\hline & 52 & $1396.7 \pm 221.4 \mathrm{a}$ & & $701.7 \pm 133.4 \mathrm{a}$ & & $2098.3 \pm 99.3 \mathrm{a}$ & & $2.1 \pm 0.8$ & & $264.1 \pm 25.2 \mathrm{a}$ & \\
\hline \multirow{3}{*}{$\begin{array}{l}\text { Acer } \\
\text { palmatum }\end{array}$} & 22 & $191.0 \pm 26.5$ & & $108.7 \pm 12.1$ & & $299.7 \pm 38.2$ & & $1.8 \pm 0.1$ & & $40.5 \pm 6.1$ & \\
\hline & 38 & $135.3 \pm 40.0$ & 3.29 & $82.7 \pm 19.7$ & 3.29 & $218.0 \pm 57.3$ & 3.29 & $1.6 \pm 0.2$ & 2.22 & $32.5 \pm 5.0$ & 2.22 \\
\hline & 52 & $193.3 \pm 37.5$ & & $105.3 \pm 12.9$ & & $298.7 \pm 49.6$ & & $1.8 \pm 0.2$ & & $36.4 \pm 5.4$ & \\
\hline \multirow{3}{*}{$\begin{array}{l}\text { Crataegus } \\
\text { pinnatifida }\end{array}$} & 22 & $488.3 \pm 30.1$ & & $416.7 \pm 55.1$ & & $905.0 \pm 43.3$ & & $1.2 \pm 0.2$ & & $136.7 \pm 36.6$ & \\
\hline & 38 & $490.0 \pm 55.7$ & 0.57 & $366.7 \pm 49.3$ & 0.57 & $856.7 \pm 102.1$ & 0.57 & $1.3 \pm 0.1$ & 0.80 & $138.6 \pm 43.7$ & 0.62 \\
\hline & 52 & $586.7 \pm 140.1$ & & $426.7 \pm 80.2$ & & $1013.3 \pm 198.6$ & & $1.4 \pm 0.3$ & & $162.6 \pm 34.6$ & \\
\hline \multirow{3}{*}{$\begin{array}{l}\text { Pinus } \\
\text { densiflora }\end{array}$} & 22 & $390.0 \pm 43.6$ & & $201.0 \pm 35.9$ & & $591.0 \pm 73.6$ & & $2.0 \pm 0.2 \mathrm{~b}$ & & $109.0 \pm 21.8 \mathrm{a}$ & \\
\hline & 38 & $401.7 \pm 38.2$ & 0.87 & $169.0 \pm 17.7$ & 0.87 & $570.7 \pm 55.9$ & 0.87 & $2.4 \pm 0.0 \mathrm{a}$ & $5.60^{*}$ & $85.5 \pm 13.4 \mathrm{~b}$ & 3.82 \\
\hline & 52 & $376.7 \pm 66.6$ & & $154.0 \pm 21.5$ & & $530.7 \pm 87.6$ & & $2.4 \pm 0.1 \mathrm{a}$ & & $92.5 \pm 19.1 \mathrm{~b}$ & \\
\hline \multirow{3}{*}{$\begin{array}{l}\text { Chionanthus } \\
\text { retusus }\end{array}$} & 22 & $433.3 \pm 28.9$ & & $393.3 \pm 94.5$ & & $826.7 \pm 106.9$ & & $1.1 \pm 0.3$ & & $104.8 \pm 20.0$ & \\
\hline & 38 & $561.7 \pm 72.5$ & 3.47 & $530.0 \pm 62.4$ & 3.47 & $1091.7 \pm 133.8$ & 3.47 & $1.1 \pm 0.0$ & 3.82 & $134.4 \pm 30.0$ & 2.49 \\
\hline & 52 & $530.0 \pm 95.4$ & & $390.0 \pm 101.5$ & & $920.0 \pm 195.2$ & & $1.4 \pm 0.2$ & & $104.7 \pm 9.7$ & \\
\hline \multirow{3}{*}{$\begin{array}{l}\text { Ilex } \\
\text { serrata }\end{array}$} & 22 & $513.3 \pm 125.0$ & & $503.3 \pm 57.5$ & & $1016.7 \pm 182.5 \mathrm{~b}$ & & $1.0 \pm 0.1$ & & $155.6 \pm 38.6$ & \\
\hline & 38 & $732.3 \pm 70.1$ & $5.40 *$ & $622.7 \pm 92.8$ & $5.40^{*}$ & $1355.0 \pm 162.2 \mathrm{a}$ & $5.40^{*}$ & $1.2 \pm 0.1$ & 3.82 & $173.0 \pm 48.6$ & 1.16 \\
\hline & 52 & $626.7 \pm 58.6$ & & $573.3 \pm 61.1$ & & $1200.0 \pm 115.3 \mathrm{a}$ & & $1.1 \pm 0.1$ & & $152.0 \pm 22.0$ & \\
\hline \multirow{3}{*}{$\begin{array}{l}\text { Viburnum } \\
\text { erosum }\end{array}$} & 22 & $532.3 \pm 84.9 \mathrm{~b}$ & & $257.7 \pm 55.1 \mathrm{~b}$ & & $790.0 \pm 139.9 \mathrm{~b}$ & & $2.1 \pm 0.1$ & & $84.0 \pm 21.2 \mathrm{~b}$ & \\
\hline & 38 & $683.3 \pm 71.8 \mathrm{a}$ & 5.42 & $416.7 \pm 60.3 \mathrm{a}$ & 5.42 & $1100.0 \pm 131.1 \mathrm{a}$ & 5.42 & $1.6 \pm 0.1$ & 5.07 & $170.0 \pm 57.9 \mathrm{a}$ & 4.36 \\
\hline & 52 & $696.7 \pm 68.1 \mathrm{a}$ & & $363.3 \pm 51.3 \mathrm{a}$ & & $1060.0 \pm 105.8 \mathrm{a}$ & & $1.9 \pm 0.2$ & & $171.0 \pm 50.9 \mathrm{a}$ & \\
\hline \multirow{3}{*}{$\begin{array}{l}\text { Hibiscus } \\
\text { syriacus }\end{array}$} & 22 & $355.0 \pm 27.8$ & & $272.0 \pm 24.3$ & & $627.0 \pm 48.4$ & & $1.3 \pm 0.1$ & & $83.9 \pm 12.7$ & \\
\hline & 38 & $384.7 \pm 84.3$ & 1.07 & $295.7 \pm 12.5$ & 1.07 & $680.3 \pm 96.2$ & 1.07 & $1.3 \pm 0.2$ & 1.42 & $89.1 \pm 20.1$ & 2.49 \\
\hline & 52 & $350.0 \pm 27.8$ & & $321.7 \pm 54.8$ & & $671.7 \pm 59.7$ & & $1.1 \pm 0.2$ & & $104.0 \pm 19.8$ & \\
\hline
\end{tabular}

$\mathrm{T} / \mathrm{R}$ Ratio $=$ Top weight/Root weight ratio; SQI $=$ Seedling weight/(H/D ratio $+\mathrm{T} / \mathrm{R}$ ratio).

${ }^{\mathrm{z}}$ Kruskal-wallis Anova.

${ }^{y}$ Post hoc test (based on Mann-whitney U test at 5\% level) after Kruskal-wallis Anova, The same letter on the column for each trees and index is not significantly different.

${ }^{* *} p<.01,{ }^{*} p<.05$.

and the total weight were highest in the $38 \mathrm{~L}$ container. Since there was no statistically significant difference between the two types, it can be grown also in the $38 \mathrm{~L}$ container. The fresh weight of the belowground part of Hibiscus syriacus was highest in the $52 \mathrm{~L}$ container, and the fresh weight of its aboveground part and the total weight were highest in the $38 \mathrm{~L}$ container. Since there was no statistically significant difference between the two types, it will be necessary to examine other indicators in a comprehensive consideration.

If photosynthates are produced more in the aboveground part in the process of cultivating seedlings, the T/R ratio of plants usually increases. If photosynthates are produced more in the belowground part to increase the use efficiency of 
nutrients and water, the T/R ratio of plants tends to decrease (Kozlowski et al., 1991). The T/R ratio of Zelkova serrata, Crataegus pinnatifida, Pinus densiflora and Ilex serrata was lowest in the $22 \mathrm{~L}$ container, and that of Acer palmatum, Chionanthus retusus and Viburnum erosum was lowest in the $38 \mathrm{~L}$ container. That of Hibiscus syriacus was lowest in the $52 \mathrm{~L}$ container. The smaller the volume of container, the lower the T/R ratio of Zelkova serrata, Crataegus pinnatifida and Pinus densiflora. The T/R ratio of Pinus densiflora only showed a statistically significant difference between different container types. The seedling quality index (SQI) of Zelkova serrata, Crataegus pinnatifida, Viburnum erosum and Hibiscus syriacus was highest in the $52 \mathrm{~L}$ container, and that of Acer palmatum and Pinus densiflora was highest in the 22 L container. That of Chionanthus retusus and Ilex serrata was highest in the $38 \mathrm{~L}$ container. A wider root collar diameter, and higher height and growth amount do not necessarily lead to a better quality of seedlings (Cho et al., 2012), and also when the aboveground and belowground parts grow in balance, it is possible to maintain the proper quality of seedlings (Cho et al., 2014). In the process of cultivating seedlings, those that have low H/D and T/R ratios, and a high SQI are assessed to be healthy seedlings (Bayala et al., 2009). Therefore, along with the growth characteristics of plants such as root collar diameter, height, and fresh weight, other indicators such as H/D and T/R ratios and SQI need to be comprehensively considered in order to determine the proper size of container for each species.

\section{Conclusions}

This study aimed to examine the physiological characteristics of landscape trees and shrubs that can be used in gardens depending on the size of container, and to determine the proper size of container for each species. Each selected species showed different physiological characteristics depending on the size of container, and considering their statistical significance, Acer palmatum, Pinus densiflora and Ilex serrata showed the highest relative growth ratio of the height and root collar diameter in the $22 \mathrm{~L}$ container; Crataegus pinnatifida in the $38 \mathrm{~L}$ container; and Zelkova serrata, Chionanthus retusus, Viburnum erosum and Hibiscus syriacus in the $52 \mathrm{~L}$ container. In terms of H/D ratio that indicates a growth balance between aboveground and belowground parts, Zelkova serrata, Pinus densiflora, Chionanthus retusus and Ilex serrata were found to be grow better in the $22 \mathrm{~L}$ container; Acer palmatum and Crataegus pinnatifida in the $38 \mathrm{~L}$ container; and Viburnum erosum and Hibiscus syriacus in the $52 \mathrm{~L}$ container. The fresh weight of Acer palmatum and Pinus densiflora was highest in the $22 \mathrm{~L}$ container; Chionanthus retusus, Ilex serrata, Viburnum erosum and Hibiscus syriacus in the $38 \mathrm{~L}$ container; and Zelkova serrata and Crataegus pinnatifida in the $52 \mathrm{~L}$ container. In terms of T/R ratio that indicates a photosynthesis balance between aboveground and belowground parts, Zelkova serrata, Crataegus pinnatifida, Pinus densiflora and Ilex serrata were found to grow better in the 22 L container; Acer palmatum, Chionanthus retusus and Viburnum erosum in the $38 \mathrm{~L}$ container; and Hibiscus syriacus in the $52 \mathrm{~L}$ container. The seedling quality index (SQI) of Acer palmatum and Pinus densiflora was highest in the $22 \mathrm{~L}$ container; Chionanthus retusus, Ilex serrata and Viburnum erosum in the $38 \mathrm{~L}$ container; and Zelkova serrata, Crataegus pinnatifida and Hibiscus syriacus in the $52 \mathrm{~L}$ container.

If the physiological characteristics and the SQI of each species, and the distribution of photosynthates are considered comprehensively, the proper size of container for each species of plants is as follows. In the case of Zelkova serrata, its height and root collar diameter continued to grow well in the $52 \mathrm{~L}$ container, and its relative growth ratio was also high in the container. Considering a balanced growth between its aboveground and belowground parts and the quality of seedlings, it is recommended to cultivate Zelkova serrata in the $52 \mathrm{~L}$ container. The height and root collar diameter of Acer palmatum continued to grow well in the $22 \mathrm{~L}$ container and its relative growth ratio and fresh weight were good in the container. Its $\mathrm{H} / \mathrm{D}$ and $\mathrm{T} / \mathrm{R}$ ratios were good in the $38 \mathrm{~L}$ container as well, but considering other factors including the 
quality of seedlings in a comprehensively manner, it can be cultivated in the $22 \mathrm{~L}$ container. The height and root collar diameter of Crataegus pinnatifida were high in the $38 \mathrm{~L}$ container, but considering factors including its fresh weight, T/R ratio and SQI in a comprehensive consideration, it is recommended to cultivate Crataegus pinnatifida in the $52 \mathrm{~L}$ container. The growth conditions and SQI of Pinus densiflora, and the balance between its aboveground and belowground parts were all good in the $22 \mathrm{~L}$ container, and thus, except large-size seedlings, it can be produced in the $22 \mathrm{~L}$ container. Chionanthus retusus grew well in the $52 \mathrm{~L}$ container, but the balance between its aboveground and belowground parts and its SQI were good in the $38 \mathrm{~L}$ container. Therefore, it would be better to cultivate Chionanthus retusus in the $38 \mathrm{~L}$ container. In the case of Ilex serrata, the balance between its aboveground and belowground parts was good in the $22 \mathrm{~L}$ container, but its fresh weight and SQI were good in the $38 \mathrm{~L}$ container. Therefore, it would be better to cultivate Ilex serrata in the $38 \mathrm{~L}$ container. Viburnum erosum grew well in the $52 \mathrm{~L}$ container, but its fresh weight and SQI were high in the $38 \mathrm{~L}$ container, showing no significant difference between the $38 \mathrm{~L}$ and $52 \mathrm{~L}$ containers. Considering its vigorous growth, it would be better to cultivate Viburnum erosum in a larger container, but from the perspective of economic feasibility, it can be cultivated also in the $38 \mathrm{~L}$ container. In the case of Hibiscus syriacus, it is recommended to cultivate it in the $52 \mathrm{~L}$ container considering factors including its growth conditions and SQI.

However, the number of trees of each plant used repeatedly in this study was not high. Different growth conditions were observed for each plant in the process of preparing trees, although species of a similar size were selected in this study. In addition, in cultivating plants in containers, the proper volume of container should be used in each stage, but the growth stage of trees of which root collar diameter was about $10 \mathrm{~cm}$ was only considered in this study. Thus, it will be necessary to conduct follow-up studies on the relationship between the growth of plants and the size of container depending on the growth stage of plants.

\section{References}

Allen, K.S., R.W. Harper, A. Bayerc, and N.J. Brazee. 2017. A review of nursery production systems and their influence on urban tree survival. Urban For. Urban Green. 21: 83-191. DOI: 10.1016/j.ufug.2016.12.002

Amoroso, G., P. Frangi, R. Piatti, F. Ferrini, A. Fini, and M. Faoro. 2010. Effect of container design on plant growth and root deformation of littleleaf linden andfield elm. HortScience 45(12):1824-1829.

Appleton, B.L. 1995. Nursery production methods for improving tree roots. J. Arboric. 21(6):265-270.

Bayala, J., M. Dianda, J. Wilson, S.J. Ouedraogo, and K. Sanon, 2009. Predicting field performance of five irrigated tree species using seedling quality assessment in Burkina Faso, West Africa. New For. 38(3):309-322. DOI: 10.1007/ s11056-009-9149-4

Burdett, A.N. 1990. Physiological processes in plantation establishment and the development of specifications for forest planting stock. Can. J. For. Res. 20(4):415-427. DOI: 10.1139/x90-059

Cho, M.S., A.R. Yang, and J.H. Hwang. 2014. Container types influence Chamaecyparis obtusa seedling growth during nursery culture. J. Korean For. Soc. 103(4):556 563. DOI: 10.14578/jkfs.2014.103.4.556

Cho, M.S., S.W. Lee, J.H. Hwang, and S.K. Kim. 2012. Growth performances of container seedlings of deciduous hardwood plantation species grown at different container types. J. Korean For. Soc. 101(2):324-332.

Cho, Y.H. 2014. A Comparison of the growth of woody landscape plants in cultivation method using Container. MS thesis, Honam University, Jeonnam, Korea.

Dana, M.N. and S.C. Blessing. 1994. Post-transplant root growth and water relations of Thuja occidentalis from field and containers. In The Landscape Below Ground. Proceedings of Int'l Workshop on Tree Root Development in Urban Soils. International Society of Arboriculture, Savoy, IL. 
Deans, J.D., W.L. Mason, M.G.R. Cannell, A.L. Sharpe, and L.J. Sheppard. 1989. Growing regimes for bare-root stock of sitka spruce, douglas fir and scots pine. 1. Morphology at the end of the nursery phase. Forestry 62:53-60.

Dominguez-Lerena, S., N.H. Sierra, I.C. Manzano, L.O. Bueno, J.L.P. Rubira, and J.G. Mexal. 2006. Container characteristics influence Pinus pinea seedling development in the nursery and field. Forest Ecology and Management 221:63-71.

Gilman, E.F., C. Harchick, and M. Paz. 2010. Effect of container type on root form andgrowth of red maple. J. Environ. Hortic. 28(1):1-7.

Grossniclke, S.C. 2012. Why seedlings survive: Influence of plant attributes. New Forest 43(5-6):711-738. DOI:10.1007/ s11056-012-9336-6

Hughes, A.P. and P.R. Freeman. 1967. Growth analysis using frequent small harvests. J. Appl. Ecol. 4(2):553-560. DOI: $10.2307 / 2401356$

Jinks, R. and B. Mason, 1998. Effects of seedling density on the growth of corsican pine, scots pine and douglas fir in containers. Ann. For. Sci. 55(4):407-423. DOI: 10.1051/forest:19980402

Jung, Y.J., B.E. Lim, and J.K. Oh, 2016. A Study for the evaluation of container modules; The technology of Korean container tree production model. J. Korean Inst. Landsc. Archit. 44(5):59-67. DOI: 10.9715/KILA.2016.44.5.059

Kang, T.H. 2008. Study on a tree production technique that used by container. MS thesis, Pusan National University, Pusan, Korea.

KFS (Korea Forest Service). 2014. Statistical yearbook of forestry. Korea Forest Service. Daejeon, Korea: Korea Forest Service. Retrieved from http://www.forest.go.kr/newkfsweb/cop/bbs/selectBoardList.do?bbsId=BBSMSTR_1064\&mn= KFS_02_03_06.

KFS (Korea Forest Service). 2016. Statistical yearbook of forestry. Korea Forest Service. Daejeon, Korea: Korea Forest Service. Retrieved from http://www.forest.go.kr/newkfsweb/cop/bbs/selectBoardList.do?bbsId=BBSMSTR_1064\&mn= KFS_02_03_06.

Kim, D.U. 2000. Effects of root restriction on growth of maple tree and sunflower. MS thesis, Catholic University of Daegu, Daegu, Korea.

Kim, D.U. and M.S. Kim. 2000. Effects of root restriction by clay pot and root control bag on growth of Acer Palmatum. J. Korean Inst. Landsc. Archit. 28(4):1-8.

Kim, M.A. 2017. September 17. Seeking for expansion of 'Container cultivation technology' to reduce the defects of landscaping trees. Landscape Architecture Korea. Retrieved from www.lak.co.kr/news/boardview.php?id=3016.

Kim, T.J. and H.B. Kim. 1999. Study on the container versus traditional landscape tree production methods. J. Hankyong Natl. Univ. 31:171-178.

Kim, T.J. and H.B. Kim. 2001. The effects of containerized landscape tree production methods on post-transplant stress. J. Korean Inst. Landsc. Archit. 29(1):152-160.

Kim, T.J. 2002. Study on the root control effects of non-woven textile growing bag. . Hankyong Natl. Univ. 33:293-300.

Kozlowski, T.T., P.J. Kramer, and S.G. Pallardy. 1991. The physiological ecology of woody plants. New York. USA: Academic Press. p.811.

Lee, C.H., C.H. Shin, K.S. Kim, and M.S. Choi. 2006. Effects of light intensity on photosynthesis and growth in seedling of Kalopanax pictus Nakai. Korean J. Med. Crop Sci. 14(4):244-249.

Lee, H.J. 2002. Studies on root development of root cutting seedlings of Aralia elata Seemann grown in plastic netting container. MS thesis. Konkuk University, Cheongju, Korea.

Ortega, U., J. Majada, A. Mena-Petite, J. Sanchez-Zabala, N. Rodriguez-Inturrizar, K. Txarterina, J. Azpitarte, and M. Dunabeitia. 2006. Field performance of Pinus radiata D. Don produced in nursery with different types of containers. New For. 31(1):97-112.

Park, Y.J. 1999. Growth characteristics of landscape trees on the size of nonwoven fabric container. J. East Coast. Res. 
10(2):49-63.

Sestak, Z., J. Catsk, and P.G. Jarvis. 1971. Plant photosynthetic production: manual of methods. The hague, Netherlands: Dr. W. Junk N.V.p. 818.

Song, K.S., Y.G. Cha, J.Y. Choi, and J.J. Kim. 2012. Comparison of growth characteristics of 1- and 2-year-old bare root and container seedling of Chamaecyparis obtusa. J. Korean For. Soc. 101(2):317-323.

Warren, S.L. and F.A. Blazich. 1991. Influence of container design on root circling, top growth and post-transplant root growth on selected landscape species. J. Environ. Hortic. 9(3):141-144. 